\title{
Neuropathic Pain after Spinal Surgery
}

\author{
Jae Hwan Cho ${ }^{1}$, Jae Hyup Lee ${ }^{2}$, Kwang-Sup Song ${ }^{3}$, Jae-Young Hong ${ }^{4}$ \\ ${ }^{1}$ Department of Orthopedic Surgery, Asan Medical Center, University of Ulsan College of Medicine, Seoul, Korea \\ ${ }^{2}$ Department of Orthopedic Surgery, SMG-SNU Boramae Medical Center, Seoul National University College of Medicine, Seoul, Korea \\ ${ }^{3}$ Department of Orthopaedic Surgery, Chung-Ang University College of Medicine, Seoul, Korea \\ ${ }^{4}$ Department of Orthopaedic Surgery, Korea University Ansan Hospital, Ansan, Korea
}

\begin{abstract}
Neuropathic pain after spinal surgery, the so-called failed back surgery syndrome (FBSS), is a frequently observed troublesome disease entity. Although medications may be effective to some degree, many patients continue experiencing intolerable pain and functional disability. Only gabapentin has been proven effective in patients with FBSS. No relevant studies regarding manipulation or physiotherapy for FBSS have been published. Spinal cord stimulation (SCS) has been widely investigated as a treatment option for chronic neuropathic pain, including FBSS. SCS was generally accepted to improve chronic back and leg pain, physical function, and sleep quality. Although the cost effectiveness of SCS has been proved in many studies, its routine application is limited considering that it is invasive and is associated with safety issues. Percutaneous epidural adhesiolysis has also shown good clinical outcomes; however, its effects persisted for only a short period. Because none of the current methods provide absolute superiority in terms of clinical outcomes, a multidisciplinary approach is required to manage this complex disease. Further studies concerning the etiology, diagnosis, treatment, and cost effectiveness of FBSS are warranted to deepen our understanding of this condition.
\end{abstract}

Keywords: Neuralgia; Failed back surgery syndrome; Spinal cord stimulation; Percutaneous adhesiolysis

\section{Introduction}

Neuropathic pain after spinal surgery is a frequently observed troublesome disease entity for both patients and surgeons [1-3]. Patients complain of persistent back or leg pain, regardless of the absence of neural compression. Neuropathic pain is frequently not matched with the dermatome and is characterized by its severity and continuity [4]. Although medications may be effective to some degree, many patients continue experiencing intolerable pain and functional disability, leading to psychological disturbances such as depression or insomnia $[5,6]$. Because the exact causes of neuropathic pain after spinal surgery have not been identified in many studies, this disease entity has been termed failed back surgery syndrome (FBSS) or post-lumbar surgery syndrome. However, this is a misnomer because it gives an impression of wrong surgery, although no definite evidence is usually found to provoke the symptoms [7]. In addition, many patients with neuropathic pain did not undergo spinal surgery. Only minor traumas, such as a mild traffic accident or falling down, can cause such severe and persistent neuropathic pain. In this respect, neuropathic pain after spinal surgery might be related to some changes in the pain modulation process [8-10], which is supported by literature showing the effectiveness of spinal cord

Received Nov 21, 2016; Revised Dec 20, 2016; Accepted Jan 3, 2017

Corresponding author: Jae Hwan Cho

Department of Orthopedic Surgery, Asan Medical Center, University of Ulsan College of Medicine,

88 Olympic-ro 43-gil, Songpa-gu, Seoul 05505, Korea

Tel: +82-2-3010-3549, Fax: +82-2-3010-8555, E-mail: spinecjh@gmail.com 
stimulation (SCS). Many studies have attempted to reveal the etiology, epidemiology, treatment, and outcomes of FBSS. However, differing definitions and involvements of heterogeneous populations make it difficult to interpret the findings of such studies. With the recent dramatic increase in understanding neuropathic pain, outcomes of various treatments for FBSS have improved. However, none of the treatments completely resolved this complex disease entity. Thus, this study aimed to review the clinical efficacy, adverse effects, and cost effectiveness of each treatment modality for patients with chronic neuropathic pain after spinal surgery.

\section{Etiology and Diagnosis of Neuropathic Pain after Spinal Surgery}

Various causes such as residual stenosis, instability, a synovial cyst, a pseudomeningocele, internal disk disruption, epidural fibrosis, facet syndrome, sacroiliac joint syndrome, reflex sympathetic dystrophy, arachnoiditis, and psychological problems have been suggested as possible etiologies of neuropathic pain after spinal surgery [1113]. Determining the exact causes are frequently difficult using magnetic resonance imaging or neurophysiological studies. In addition, sagittal imbalance or back muscle problems can be potential causes of persistent pain [1416]. The difficulties in diagnosis lead to easy failure of any treatment. Revision surgical treatment reportedly showed an inferior efficacy if the structural causes were not preoperatively identified $[17,18]$. Thus, careful history taking, physical examination, and reviews of pre- and postoperative status are considered basic and fundamental criteria for diagnosing FBSS.

The diagnosis of FBSS is somewhat vague and not universal and is considered to include heterogeneous patients who exhibit residual symptoms after spinal surgery. The difficulty in defining this complex disease entity has been well described [19]. However, doctors recognize this characteristic disease, which is supported by one survey study [20]. Although the Douleur Neuropathique en 4 and Leeds Assessment of Neuropathic Symptoms have been suggested as screening tools for neuropathic pain [21], they are less reliable for identifying the neuropathic component of FBSS [22]. This diagnostic ambiguity is an obstacle in the clinical effectiveness of each treatment modality.

\section{Clinical Outcomes of Each Treatment}

\section{Medication}

Only gabapentin has been proven effective in patients with FBSS. In one randomized controlled trial, gabapentin, at a daily maximal dose of $1,800 \mathrm{mg}$, showed more clinical efficacy than naproxen [23]. Oral gabapentin with an epidural steroid injection showed better results than the injection alone [24]. Pregabalin also has a preventive analgesic effect on postoperative neuropathic pain [25]. Nonsteroidal antiinflammatory drugs have minimal effects on FBSS [23]. The effect of antidepressants has not been reported. Although oral opioid is frequently used to relieve severe pain, its effectiveness in patients with FBSS is limited [26].

\section{Exercise, manipulation, and physiotherapy}

Only few studies have reported regarding the effect of exercise, manipulation, or physiotherapy on FBSS. A recent study evaluating different exercise programs reported that isokinetic or dynamic lumbar stabilization exercises were more effective than home exercises [27]. No relevant articles have been found regarding the effect of manipulation or physiotherapy on FBSS. Only one retrospective study showed the efficacy of chiropractic management of lumbar spine pain after spinal surgery [28].

\section{Spinal cord stimulation}

SCS has been widely investigated as a treatment option for chronic neuropathic pain, including FBSS. SCS was generally accepted to improve chronic back and leg pain, physical function, and sleep quality $[29,30]$. The degree of evidence was qualified in one systematic review, which showed level II-1 or II-2 by the U.S. Preventive Services Task Force for long-term relief [31]. Moreover, numerous studies have shown SCS effectiveness (Table 1) [31-53]. Two randomized controlled trials compared SCS effectiveness with other treatments. A 2-year follow-up study demonstrated the effectiveness of SCS and medication in $48 \%$ and $9 \%$ of patients, respectively [54]. In the other study, SCS was more effective than repeated spinal surgery ( $47 \%$ vs. $12 \%, p<0.01)$ [55]. Regardless of its invasiveness and several complications, SCS is considered to be a relatively safe technique [56]. 
Table 1. Observational studies to reveal the effectiveness of spinal cord stimulation for FBSS

\begin{tabular}{|c|c|c|c|c|}
\hline Study & $\begin{array}{l}\text { No. of } \\
\text { patients }\end{array}$ & Specific methods & $\begin{array}{l}\text { Follow-up } \\
\text { (yr) }\end{array}$ & Conclusion \\
\hline De La Porte et al. [32] & 78 & $\begin{array}{l}\text { SCS with unipolar } \\
\text { wire-type electrode }\end{array}$ & 4 & $\begin{array}{l}\text { The } 64 \text { patients were successful during trial period. } \\
\text { Among them, the } 35 \text { patients continued to experience } \\
\text { at least } 50 \% \text { pain relief at the latest follow-up. }\end{array}$ \\
\hline de Vos et al. [33] & 45 & SCS with hybrid lead & 0.5 & $\begin{array}{l}\text { Of } 42 \text { patients, the VAS of LBP and leg pain decreased } \\
\text { from } 8.0 \text { and } 7.5 \text { to } 3.2 \text { and } 3.5 \text {, respectively }(p<0.001) \text {. }\end{array}$ \\
\hline Devulder et al. [34] & 69 & $\begin{array}{l}\text { SCS with a radiofrequen- } \\
\text { cy-coupled or battery } \\
\text { system }\end{array}$ & 13 & $\begin{array}{l}\text { Forty-three patients continued with the therapy and } \\
\text { experienced good pain relief. }\end{array}$ \\
\hline LeDoux et al. [35] & 32 & SCS & 2 & $\begin{array}{l}74 \% \text { of the } 19 \text { patients with stimulators still present at } 2 \\
\text { years were experiencing } 50 \% \text { or better pain relief. }\end{array}$ \\
\hline North et al. [36] & 50 & $\begin{array}{l}\text { SCS with percutaneous } \\
\text { method }\end{array}$ & 5 & $\begin{array}{l}\text { Successful outcome was recorded in } 53 \% \text { of the patients } \\
\text { at } 2.2 \text { years and in } 47 \% \text { of the patients at } 5.0 \text { years } \\
\text { postoperatively. }\end{array}$ \\
\hline North et al. [37] & 20 & $\begin{array}{l}\text { SCS with single and dual } \\
\text { percutaneous electrode }\end{array}$ & 2.3 & $\begin{array}{l}\text { Technical success was achieved with single and dual } \\
\text { electrodes in most patients. At the } 2.3-\text { year average } \\
\text { follow-up, the } 19 \text { available patients (95\%) reported } 46 \% \\
\text { average relief of LBP. }\end{array}$ \\
\hline Ohnmeiss et al. [38] & 41 & Mattrix system & 1.5 & $\begin{array}{l}\text { Sixty percent of patients considered themselves improved. } \\
69 \% \text { were satisfied. }\end{array}$ \\
\hline Rainov et al. [39] & 32 & $\begin{array}{l}\text { SCS with quadripolar } \\
\text { leads }\end{array}$ & 3.5 & $\begin{array}{l}\text { Follow-ups of } 2 \text { to } 3.5 \text { years after lead implantation pro- } \\
\text { vided stable analgesia and a good outcome in } 25 \text { patients. }\end{array}$ \\
\hline Vonhogen et al. [40] & 20 & $\begin{array}{l}\text { SCS with a small profile } \\
\text { plate type lead, S-series }\end{array}$ & 1 & $\begin{array}{l}\text { A significant reduction of } 43 \% \text { and } 27 \% \text {, respectively, in } \\
\text { VAS legs and VAS back pain was found at postoperative } \\
1 \text { year. In } 17 \text { patients ( } 85 \% \text { ) a clinically relevant reduction } \\
\text { (reduction of } 2 \text { points or } 30 \% \text { in VAS) was seen. }\end{array}$ \\
\hline Dario et al. [41] & 24 & $\begin{array}{l}\text { SCS with quadripolar } \\
\text { leads }\end{array}$ & 3.5 & $\begin{array}{l}\text { All but two patients treated with SCS demonstrated good } \\
\text { results regarding leg pain; whereas there were } \\
\text { poor results regarding back pain. }\end{array}$ \\
\hline Wille et al. [42] & 20 & $\begin{array}{l}\text { HF SCS with } 2 \text { eight } \\
\text { polar leads }\end{array}$ & 1 & $\begin{array}{l}\text { At } 12 \text { months, the pain scores, functional status, and } \\
\text { quality of life scores were still } 50 \% \text { better than the initial } \\
\text { scores }\end{array}$ \\
\hline Wille et al. [43] & 20 & $\begin{array}{l}\text { Medtronic Specify 5-6-5 } \\
\text { lead }\end{array}$ & 0.5 & $\begin{array}{l}\text { Pain scores, the disability, and quality of life scores } \\
\text { improved significantly in this patient group. }\end{array}$ \\
\hline Vangeneugden [44] & 24 & $\begin{array}{l}\text { Medtronic Specify 5-6-5 } \\
\text { lead }\end{array}$ & 1.4 & All 21 patients have at present more than $50 \%$ pain relief. \\
\hline Seijo et al. [45] & 43 & SCS & 3.0 & $\begin{array}{l}\text { Excellent in } 32 \% \text {, good in } 32 \% \text {, poor in } 18 \% \text {, and failure } \\
\text { in } 18 \% \text { resulted. }\end{array}$ \\
\hline Rigoard et al. [46] & 76 & Multicolumn SCS & 0.5 & $\begin{array}{l}\text { At six months, } 75.4 \% \text { and } 42.1 \% \text { of the patients obtained } \\
\text { at least } 30 \% \text { and } 50 \% \text { improvement of their back pain } \\
\text { VAS score, respectively. }\end{array}$ \\
\hline Miller et al. [47] & 17 & SCS with $2 X 4$ lead & 0.7 & $\begin{array}{l}\text { Fifteen patients reported at least } 50 \% \text { reduction in both } \\
\text { lower back and leg pain on the VAS scale. Overall, } \\
\text { patients obtained an average of } 84 \% \text { and } 76 \% \\
\text { improvement in leg and back pain, respectively. }\end{array}$ \\
\hline Leveque et al. [48] & 30 & $\begin{array}{l}\text { SCS with quadripolar } \\
\text { electrode }\end{array}$ & 2.8 & $\begin{array}{l}\text { Overall, } 12 \text { of the } 16 \text { patients ( } 75 \% \text { ) who received } \\
\text { permanent implants continued to report at least } 50 \% \\
\text { relief of pain at follow-up. }\end{array}$ \\
\hline Gatzinsky et al. [49] & 71 & SCS with octopolar lead & 1.0 & $\begin{array}{l}\text { Responders (pain reduction } \geq 50 \% \text { ) at } 12 \text { months were } \\
66 \% \text { (44/67) for leg pain and } 36 \% \text { (24/67) for back pain. }\end{array}$ \\
\hline
\end{tabular}


Table 1. Continued

\begin{tabular}{lclcl} 
Study & $\begin{array}{c}\text { No. of } \\
\text { patients }\end{array}$ & Specific methods & $\begin{array}{c}\text { Follow-up } \\
\text { (yr) }\end{array}$ & \multicolumn{1}{c}{ Conclusion } \\
\hline De Vos et al. [50] & 40 & $\begin{array}{l}\text { SCS with percutaneous } \\
\text { paddle leads }\end{array}$ & 1.0 & $\begin{array}{l}\text { Twelve months after implantation the average pain } \\
\text { scores for back and legs have been halved. }\end{array}$ \\
\hline Carballa et al. [51] & 53 & SCS with surgical leads & 1.8 & $\begin{array}{l}\text { The median pain decrease was } 68 \% ; 84 \% \text { of patients } \\
\text { reported a pain decrease greater than or equal to } 50 \% .\end{array}$ \\
\hline Al-Kaisy et al. [52] & 67 & HF-SCS & 1.0 & $\begin{array}{l}\text { Seventy percent of the patients had } \geq 50 \% \text { back pain } \\
\text { relief at } 12 \text { months compared to baseline. }\end{array}$ \\
\hline Abeloos et al. [53] & 55 & SCS & 8.3 & $\begin{array}{l}\text { Seventy-five percent of our patient population report a } \\
\text { pain decrease of }>50 \% .\end{array}$ \\
\hline
\end{tabular}

FBSS, failed back surgery syndrome; SCS, spinal cord stimulation; VAS, visual analog scale; LBP, low back pain; HF, high frequency.

Table 2. Observational studies to reveal the effectiveness of epidural adhesiolysis for FBSS

\begin{tabular}{|c|c|c|c|c|}
\hline Study & $\begin{array}{c}\text { No. of } \\
\text { patients }\end{array}$ & Specific methods & $\begin{array}{l}\text { Follow-up } \\
\text { (yr) }\end{array}$ & Conclusions \\
\hline Avellanal et al. [59] & 19 & $\begin{array}{l}\text { Epiduroscopic adhesiolysis } \\
\text { (interlaminar approach) }\end{array}$ & 0.5 & $\begin{array}{l}\text { The VAS score decreased from } 7.89 \text { to } 5.95(p<0.001) \\
\text { and } 6.05(p<0.001) \text { at } 3 \text { and } 6 \text { months. } \\
\text { Six patients }(31.6 \%) \text { did not show improvement. }\end{array}$ \\
\hline Takeshima et al. [60] & 28 & $\begin{array}{l}\text { Epiduroscopic adhesiolysis } \\
\text { through sacral hiatus }\end{array}$ & 0.5 & $\begin{array}{l}\text { Among patients in whom the nerve root was responsible } \\
\text { for radicular pain was separated, there was a long-term } \\
(6 \mathrm{mo}) \text { improvement in the RDO, ODI, and JOA scores. }\end{array}$ \\
\hline Lee et al. [61] & 114 & $\begin{array}{l}\text { Percutaneous adhesiolysis } \\
\text { (PA) vs. TFESI }\end{array}$ & 0.5 & $\begin{array}{l}\text { The proportion of successful results was higher for the } \\
\text { PA group than for the TFESI group regarding the NRS } \\
\text { and ODI scores at six months. }\end{array}$ \\
\hline Gruyters et al. [62] & 34 & $\begin{array}{l}\text { Epiduroscopic adhesiolysis } \\
\text { through sacral hiatus }\end{array}$ & 0.5 & $\begin{array}{l}\text { Epiduroscopy with full adhesiolysis of epidural fibrosis } \\
\text { resulting in a better clinical outcome is more readily } \\
\text { achievable after discectomy and laminectomy } \\
\text { procedures, as opposed to ALIF- or PLIF-surgery. }\end{array}$ \\
\hline Geypen et al. [63] & 41 & Endoscopic adhesiolysis & 3.8 & $\begin{array}{l}\text { Of } 41 \text { patients, } 11 \text { had a GPE }>50 \% \text { at } 6 \text { months, } \\
\text { and seven patients had a GPE }>50 \% \text { improvement } \\
\text { at the time of inquiry. }\end{array}$ \\
\hline
\end{tabular}

FBSS, failed back surgery syndrome; VAS, visual analog scale; RDQ, Roland-Morris Disability Questionnaire; ODI, Oswestry disability index; JOA, Japanese Orthopaedic Association; TFESI, transforaminal epidural steroid injection; NRS, numeric rating scale; ALIF, anterior lumbar interbody fusion; PLIF, posterior lumbar interbody fusion; GPE, global perceived effect.

\section{Epidural adhesiolysis}

Epidural adhesiolysis releases epidural fibrosis, which could be a source of pain [57]. Manchikanti et al. [58] revealed superior clinical outcomes with epidural adhesiolysis compared with an epidural steroid injection at 1-year follow-up. In addition, several studies showed the shortterm (6 months) effectiveness of percutaneous adhesiolysis (Table 2) [59-63]. These findings were supported by recent systematic reviews [64-66]. Complication rates are high in epidural adhesiolysis [67].

\section{Injection therapy}

Studies that support the effectiveness of injection therapy in FBSS are limited. Although patients who underwent an epidural steroid injection showed immediate improvement, the effect of the therapy deteriorated at 1-, 3-, and 6-month follow-ups $[68,69]$. The differences of clinical outcomes on the basis of injection materials remains unclear [68,70].

\section{Radiofrequency therapy}

There have been few attempts to use radiofrequency to 
Table 3. Observational studies to reveal the effectiveness of reoperation for FBSS

\begin{tabular}{|c|c|c|c|c|}
\hline Study & $\begin{array}{l}\text { No. of } \\
\text { patients }\end{array}$ & Specific method & $\begin{array}{l}\text { Follow-up } \\
\quad(y r)\end{array}$ & Conclusion \\
\hline Arts et al. [73] & 100 & Fusion with instrumentation & 1.3 & $\begin{array}{l}\text { Thirty-five percent reported a good outcome, whereas } \\
65 \% \text { had unsatisfactory outcomes. }\end{array}$ \\
\hline Biondi et al. [74] & 45 & $\begin{array}{l}\text { Redecompression, neural } \\
\text { exploration, and fusion }\end{array}$ & 2.4 & $\begin{array}{l}\text { Forty-seven percent good, } 22 \% \text { fair, } 31 \% \text { poor results. } \\
\text { Worker's compensation, }<6 \text { mo pain-free interval, } \\
\text { male, psychiatric disease, and perineural fibrosis were } \\
\text { associated with the poor result. }\end{array}$ \\
\hline Duggal et al. [75] & 33 & ALIF & 1.0 & $\begin{array}{l}\text { Back pain, leg pain, and functional status improved } \\
\text { significantly, by } 76 \%, 80 \% \text {, and } 67 \%(p<0.01) \text {, } \\
\text { respectively. }\end{array}$ \\
\hline Fritsch et al. [76] & 136 & $\begin{array}{l}\text { Lumbar discectomy } \\
\text { followed by reintervention }\end{array}$ & 2-27 & $\begin{array}{l}80 \% \text { of the patients reported satisfactory outocome in } \\
\text { the short-term follow-up, and it decreased to } 22 \% \text { in the } \\
\text { long-term follow-up. }\end{array}$ \\
\hline $\begin{array}{l}\text { Markwalder et al. } \\
\text { [77] }\end{array}$ & 171 & $\begin{array}{l}\text { Stabilization after } \\
\text { confirming instability }\end{array}$ & 2.0 & $\begin{array}{l}\text { Excellent, good, satisfactory, moderate, and poor results } \\
\text { in } 87(53 \%), 42(26 \%), 23(14 \%), 9(6 \%) \text {, and } 2(1 \%) \\
\text { patients, respectively. }\end{array}$ \\
\hline North et al. [78] & 102 & $\begin{array}{l}\text { Decompression and/or } \\
\text { stabilization }\end{array}$ & 5.0 & $\begin{array}{l}\text { A successful outcome was recorded in } 34 \% \text { of the } \\
\text { patients. }\end{array}$ \\
\hline Skaf et al. [79] & 50 & $\begin{array}{l}\text { Removal of residual disc, } \\
\text { release of adhesions with } \\
\text { decompression and fusion }\end{array}$ & 1.0 & $\begin{array}{l}\text { A successful outcome (>50\% pain relief) was achieved } \\
\text { in } 92 \% \text { of the patients at } 1 \text { year. }\end{array}$ \\
\hline $\begin{array}{l}\text { Delamarter et al. } \\
\text { [80] }\end{array}$ & 674 & TDR & 2.0 & $\begin{array}{l}\text { In properly selected patients with previously failed } \\
\text { lumbar surgery, TDR can provide significant clinical } \\
\text { improvement. }\end{array}$ \\
\hline
\end{tabular}

FBSS, failed back surgery syndrome; ALIF, anterior lumbar interbody fusion; TDR, total disc replacement.

control pain in FBSS. In one study, pulse radiofrequency of the dorsal root ganglion showed good results for three patients during a short-term period [71]. In another study, radiofrequency neurotomy was successful if zygapophysial joint pain existed in patients with FBSS [72].

\section{Surgical treatment}

Many studies have revealed the effectiveness of various surgeries, including repeated decompression, instrumented fusion, release of adhesion, or total disk replacement (Table 3) [73-80]. However, varying success rates, ranging from $35 \%$ to $92 \%$, have been reported in a short-term (1 year) follow-up. This clinical effect has been significantly aggravated in long-term follow-ups.

\section{Cost Effectiveness}

Cost effectiveness is another important consideration for evaluating outcomes per unit, as well as insurance policy recommendations. Because of the considerable economic burden of FBSS, a cost-effectiveness analysis should be performed [81]. Many authors have suggested that SCS is more cost effective than conventional medication or surgery as a treatment of FBSS, regardless of the initial high cost [82-85]. This cost effectiveness is unclear in patients receiving workers' compensation [86]. Overall, the costeffectiveness analyses of SCS for FBSS are summarized in Table $4[84,85,87,88]$. Besides SCS, only one study supported the cost effectiveness of long-term intrathecal morphine therapy [89]. No studies have been found regarding the cost effectiveness of percutaneous epidural adhesiolysis.

\section{Discussion}

FBSS is a challenge for surgeons, pain specialists, and primary care providers because of its vague etiology and lack of definite treatment protocols, thereby requiring a multidisciplinary treatment approach [11]. Thorough history taking, physical examination, and careful reviews of 
Table 4. Cost-effectiveness analyses of spinal cord stimulation for FBSS

\begin{tabular}{|c|c|c|c|c|}
\hline Study & $\begin{array}{c}\text { No. of } \\
\text { patients }\end{array}$ & Comparisons & $\begin{array}{c}\text { Follow-up } \\
(y r)\end{array}$ & Conclusion \\
\hline Zucco et al. [85] & 80 & SCS only & 2 & $\begin{array}{l}\text { The EQ- } 5 \text { D utility index increased from } 0.421 \text { to } 0.630 \text {. If } \\
\text { the willing to pay per OALY was } 60,000 \text { euros, then SCS } \\
\text { would be cost-effective in } 80 \%-85 \% \text {. }\end{array}$ \\
\hline North et al. [84] & 42 & SCS vs. reopeartion & 3.1 & $\begin{array}{l}\text { SCS was dominant (more effective and less expensive) in } \\
\text { the incremental cost-effectiveness ratios. A bootstrapped } \\
\text { simulation for incremental costs and QALY confirmed } \\
\text { SCS's dominancy, with } 72 \% \text { of the cost results occurring } \\
\text { below US policymaker's maximum WTP threshold. }\end{array}$ \\
\hline Taylor et al. [87] & From 2 RCTs & SCS vs. CMM & 2 & $\begin{array}{l}\text { SCS was dominant over the lifetime of the patient. The } \\
\text { 2-year cost-effectiveness of SCS ranged from } 30,370 \text { to } \\
63,511 \text { Euros. }\end{array}$ \\
\hline Manca et al. [88] & 100 & SCS vs. CMM & 0.5 & $\begin{array}{l}\text { The addition of SCS to CMM results in higher costs but } \\
\text { also generates important improvement in patients' EQ-5D } \\
\text { over the same period. }\end{array}$ \\
\hline
\end{tabular}

FBSS, failed back surgery syndrome; SCS, spinal cord stimulation; EQ-5D, Euro0ol 5-dimensions questionnare; QALY, quality-adjusted life years; WTP, willingness to pay; RCT, randomized controlled trial; CMM, conventional medical management.

imaging are required, followed by the establishment of adequate treatment strategies. Because conventional medical treatments have been considered ineffective, the efficacy, safety, and cost effectiveness of other interventional modalities have been widely investigated.

Among the various interventions, research on SCS has been increasing; SCS is reportedly effective, relatively safe, and cost effective. To relieve pain, SCS is considered to activate dorsal column fibers, which suppress the neuronal activity by activating inhibitory interneurons [90]. Most studies regarding the efficacy of SCS have been retrospective case series, which could contain an intention bias by investigators. Because SCS is an invasive procedure, it is not considered as a primary treatment for FBSS. Complications associated with SCS are not negligible. The most commonly reported complications include hardware malfunction and wound infection [91]. However, fatal complications such as epidural hematoma or spinal cord injury could occur. Nevertheless, as a last resort, a temporary insertion of a cord stimulator can be considered. If it had good clinical outcomes, then a permanent insertion is considered. Several studies suggested an algorithm to manage FBSS with SCS $[92,93]$. The technology of SCS has dramatically developed. The efficacy of SCS may increase by new leads in a multicolumn design and a greater number of contact sites (ESTIMET study) [94,95].

Percutaneous epidural adhesiolysis was originally de- veloped to remove the epidural adhesion by surgical intervention, annular tear, or inflammatory response [57]. It reportedly had a strong short-term (3 months) efficacy and moderate long-term ( $>3$ months) efficacy in patients with chronic low back pain [96]. In a recently published systematic review, percutaneous adhesiolysis was efficient in patients with lumbar post-surgery syndrome with level II evidence by Interventional Pain Management Techniques-Quality Appraisal of Reliability and Risk for Bias Assessment [66]. Although weak positive evidence exists regarding epidural adhesiolysis being more effective than epidural steroid injection in FBSS, the complication rates are also higher [67].

Injection therapy can be used as a primary treatment on the basis of its procedure simplicity and rare complications. The various injection procedures include epidural injection (caudal, transforaminal), sympathetic nerve block, intrathecal injection, prolotherapy, and a combination therapy [68,97-99]. Regardless of the various therapeutic approaches, temporary clinical improvements and lack of a control group are considered to be limitations of studies. More studies are required to reveal the efficacy of radiofrequency therapy.

Surgical management of FBSS showed only limited evidence with variable outcomes, likely caused by the vague definition of FBSS. If a study included surgically correctable cases (i.e., residual stenosis, instability, or disk degen- 
eration), then the clinical outcomes could obviously be improved after careful diagnostic procedures. Therefore, the outcomes of revision surgery for chronic neuropathic pain after index spinal surgery are judged to be ineffective.

Because no single approach has produced excellent results, a multidisciplinary approach is required to manage patients with FBSS. Chronic pain is related to psychological distress after lumbar surgery $[100,101]$. Thus, psychological control is also important. Concurrent rehabilitation by exercise or physiotherapy will be helpful to enhance the clinical effect of other interventions.

\section{Conclusions}

FBSS is considered troublesome for both patients and doctors because it usually does not respond to conventional medication or injection therapy. Although the literature reports relatively good clinical outcomes and cost effectiveness with the use of SCS, its routine application should be limited considering that it is invasive and is associated with safety issues. Meanwhile, although epidural adhesiolysis has shown good clinical outcomes, its effects persisted for only a short period. A multidisciplinary treatment approach is required to manage this complex disease entity because none of the current methods provide absolute superiority. Further studies regarding the etiology, diagnosis, treatment, and cost effectiveness of FBSS are warranted to deepen our understanding of the condition.

\section{Conflict of Interest}

No potential conflict of interest relevant to this article was reported.

\section{References}

1. Chan CW, Peng P. Failed back surgery syndrome. Pain Med 2011;12:577-606.

2. Thomson S. Failed back surgery syndrome: definition, epidemiology and demographics. Br J Pain 2013; 7:56-9.

3. Thomson S, Jacques L. Demographic characteristics of patients with severe neuropathic pain secondary to failed back surgery syndrome. Pain Pract 2009;9:20615.

4. Long DM, Filtzer DL, BenDebba M, Hendler NH.
Clinical features of the failed-back syndrome. J Neurosurg 1988;69:61-71.

5. Yalbuzdag SA, Erol AM, Sengul I, et al. Temperament and character profile in failed back surgery syndrome: a cross-sectional clinical study. Turk Neurosurg 2016;26:912-7.

6. Monlezun O, Lode-Kolz K, Roulaud M, et al. A prospective study evaluating sleep quality in Failed Back Surgery Syndrome patients treated by multicolumn spinal cord stimulation: study design protocol and presentation of the study population. Neurochirurgie 2015;61 Suppl 1:S117-24.

7. Rigoard P, Desai MJ, Taylor RS. Failed back surgery syndrome: what's in a name? A proposal to replace "FBSS" by "POPS". Neurochirurgie 2015;61 Suppl 1:S16-21.

8. De Andres J, Van Buyten JP. Neural modulation by stimulation. Pain Pract 2006;6:39-45.

9. Kishima H, Saitoh Y, Oshino S, et al. Modulation of neuronal activity after spinal cord stimulation for neuropathic pain; H(2)15O PET study. Neuroimage 2010;49:2564-9.

10. Kornelsen J, Sboto-Frankenstein U, McIver T, et al. Default mode network functional connectivity altered in failed back surgery syndrome. J Pain 2013; 14:483-91.

11. Baber Z, Erdek MA. Failed back surgery syndrome: current perspectives. J Pain Res 2016;9:979-87.

12. Bokov A, Isrelov A, Skorodumov A, Aleynik A, Simonov A, Mlyavykh S. An analysis of reasons for failed back surgery syndrome and partial results after different types of surgical lumbar nerve root decompression. Pain Physician 2011;14:545-57.

13. Rigoard P, Blond S, David R, Mertens P. Pathophysiological characterisation of back pain generators in failed back surgery syndrome (part B). Neurochirurgie 2015;61 Suppl 1:S35-44.

14. Jang JS, Lee SH, Min JH, Kim SK, Han KM, Maeng DH. Surgical treatment of failed back surgery syndrome due to sagittal imbalance. Spine (Phila Pa 1976) 2007;32:3081-7.

15. Bordoni B, Marelli F. Failed back surgery syndrome: review and new hypotheses. J Pain Res 2016;9:17-22.

16. Zoidl G, Grifka J, Boluki D, et al. Molecular evidence for local denervation of paraspinal muscles in failedback surgery/postdiscotomy syndrome. Clin Neuropathol 2003;22:71-7. 
17. Assaker R, Zairi F. Failed back surgery syndrome: to re-operate or not to re-operate? A retrospective review of patient selection and failures. Neurochirurgie 2015;61 Suppl 1:S77-82.

18. Kim SS, Michelsen CB. Revision surgery for failed back surgery syndrome. Spine (Phila Pa 1976) 1992; 17:957-60.

19. Al Kaisy A, Pang D, Desai MJ, et al. Failed back surgery syndrome: who has failed? Neurochirurgie 2015;61 Suppl 1:S6-14.

20. Tharmanathan P, Adamson J, Ashby R, Eldabe S. Diagnosis and treatment of failed back surgery syndrome in the UK: mapping of practice using a crosssectional survey. Br J Pain 2012;6:142-52.

21. Hamdan A, Luna JD, Del Pozo E, Galvez R. Diagnostic accuracy of two questionnaires for the detection of neuropathic pain in the Spanish population. Eur J Pain 2014;18:101-9.

22. Markman JD, Kress BT, Frazer M, Hanson R, Kogan V, Huang JH. Screening for neuropathic characteristics in failed back surgery syndromes: challenges for guiding treatment. Pain Med 2015;16:520-30.

23. Khosravi MB, Azemati S, Sahmeddini MA. Gabapentin versus naproxen in the management of failed back surgery syndrome: a randomized controlled trial. Acta Anaesthesiol Belg 2014;65:31-7.

24. Zencirci B. Analgesic efficacy of oral gabapentin added to standard epidural corticosteroids in patients with failed back surgery. Clin Pharmacol 2010;2:207-11.

25. Canos A, Cort L, Fernandez Y, et al. Preventive analgesia with pregabalin in neuropathic pain from "failed back surgery syndrome": assessment of sleep quality and disability. Pain Med 2016;17:344-52.

26. Anderson JT, Haas AR, Percy R, Woods ST, Ahn UM, Ahn NU. Chronic opioid therapy after lumbar fusion surgery for degenerative disc disease in a workers' compensation setting. Spine (Phila Pa 1976) 2015;40:1775-84.

27. Karahan AY, Sahin N, Baskent A. Comparison of effectiveness of different exercise programs in treatment of failed back surgery syndrome: a randomized controlled trial. J Back Musculoskelet Rehabil 2016 Jun 17 [Epub]. https://doi.org/ 10.3233/BMR-160722.

28. Kruse RA, Cambron J. Chiropractic management of postsurgical lumbar spine pain: a retrospective study of 32 cases. J Manipulative Physiol Ther 2011;34:40812.
29. Taylor RS, Desai MJ, Rigoard P, Taylor RJ. Predictors of pain relief following spinal cord stimulation in chronic back and leg pain and failed back surgery syndrome: a systematic review and meta-regression analysis. Pain Pract 2014;14:489-505.

30. Kelly GA, Blake C, Power CK, O’Keeffe D, Fullen BM. The impact of spinal cord stimulation on physical function and sleep quality in individuals with failed back surgery syndrome: a systematic review. Eur J Pain 2012;16:793-802.

31. Frey ME, Manchikanti L, Benyamin RM, Schultz DM, Smith HS, Cohen SP. Spinal cord stimulation for patients with failed back surgery syndrome: a systematic review. Pain Physician 2009;12:379-97.

32. De La Porte C, Van de Kelft E. Spinal cord stimulation in failed back surgery syndrome. Pain 1993;52: 55-61.

33. de Vos CC, Bom MJ, Vanneste S, Lenders MW, de Ridder D. Burst spinal cord stimulation evaluated in patients with failed back surgery syndrome and painful diabetic neuropathy. Neuromodulation 2014; 17:152-9.

34. Devulder J, De Laat M, Van Bastelaere M, Rolly G. Spinal cord stimulation: a valuable treatment for chronic failed back surgery patients. J Pain Symptom Manage 1997;13:296-301.

35. LeDoux MS, Langford KH. Spinal cord stimulation for the failed back syndrome. Spine (Phila Pa 1976) 1993;18:191-4.

36. North RB, Kidd DH, Olin J, et al. Spinal cord stimulation for axial low back pain: a prospective, controlled trial comparing dual with single percutaneous electrodes. Spine (Phila Pa 1976) 2005;30:1412-8.

37. North RB, Ewend MG, Lawton MT, Kidd DH, Piantadosi S. Failed back surgery syndrome: 5-year follow-up after spinal cord stimulator implantation. Neurosurgery 1991;28:692-9.

38. Ohnmeiss DD, Rashbaum RF. Patient satisfaction with spinal cord stimulation for predominant complaints of chronic, intractable low back pain. Spine J 2001;1:358-63.

39. Rainov NG, Heidecke V, Burkert W. Short test-period spinal cord stimulation for failed back surgery syndrome. Minim Invasive Neurosurg 1996;39:41-4.

40. Vonhogen LH, Vancamp T, Vanneste S, et al. Percutaneously implanted plates in failed back surgery syndrome (FBSS). Neuromodulation 2011;14:319-24. 
41. Dario A, Fortini G, Bertollo D, Bacuzzi A, Grizzetti C, Cuffari S. Treatment of failed back surgery syndrome. Neuromodulation 2001;4:105-10.

42. Wille F, Breel J, Dikkeboer J. Spinal cord stimulation for FBSS with significant low back pain. Neuromodulation 2011;14:464.

43. Wille F, Breel J, Hollmann M. High frequency stimulation with a single 8-polar lead: one year follow-up: spine. Neuromodulation 2013;16:e139.

44. Vangeneugden J. Specify 5-6-5 electrode (Medtronic) for treatment of failed back syndrome: results in 24 patients with a mean follow up of 17 months. Neuromodulation 2011;14:468.

45. Seijo F, Moreno JM, Jaradat M, Lopez JM. Spinal cord stimulation in post-surgical low back pain. Pain Clin 1993;6:241-7.

46. Rigoard P, Jacques L, Monlezun O, et al. Treatment of the back pain component of failed back surgery syndrome (FBSS) by multi-column spinal cord stimulation: a multicentre prospective study. Neuromodulation 2013;16:e218.

47. Miller JP, Leizman D. Combined spinal cord and subcutaneous neurostimulation for back and leg pain due to failed back surgery syndrome. Neurosurgery 2010;67:550.

48. Leveque JC, Villavicencio AT, Bulsara KR, Rubin L, Gorecki JP. Spinal cord stimulation for failed back surgery syndrome. Neuromodulation 2001;4:1-9.

49. Gatzinsky K, Ver Donck A, Baardsen R, Buschman R. Octad study: evaluation of the effectiveness of octopolar leads in patients with failed back surgery syndrome with chronic low back and/or leg pain during a one year follow-up period. A prospective, multicentre, open-label, non-randomized study. Neuromodulation 2013;16:e83.

50. De Vos CC, Dijkstra C, Lenders MW. Pain reduction in back and legs with percutaneous paddle leads. Eur J Pain Suppl 2010;4:113.

51. Carballal CF, Sierra OM, Vallejo BI, Juretschke FR, Useros TP. Spinal cord stimulation for patients with failed back surgery syndrome. Neuromodulation 2013;16:e75.

52. Al-Kaisy A, Van Buyten JP, Smet I, Palmisani S, Smith T. High frequency spinal cord stimulation (HF-SCS) therapy in failed back: Surgerysyndrome (FBSS) patients with predominant back pain. Eur Spine J 2013;22(1 Suppl):S56.
53. Abeloos L, De Witte O, Riquet R, Tuna T, Mathieu N. Long-term outcome of patients treated with spinal cord stimulation for therapeutically refractory failed back surgery syndrome: a retrospective study. Neurochirurgie 2011;57:114-9.

54. Kumar K, North R, Taylor R, et al. Spinal cord stimulation vs. conventional medical management: a prospective, randomized, controlled, multicenter study of Patients with Failed Back Surgery Syndrome (PROCESS Study). Neuromodulation 2005;8:213-8.

55. North RB, Kumar K, Wallace MS, et al. Spinal cord stimulation versus re-operation in patients with failed back surgery syndrome: an international multicenter randomized controlled trial (EVIDENCE study). Neuromodulation 2011;14:330-5.

56. Bendersky D, Yampolsky C. Is spinal cord stimulation safe? A review of its complications. World Neurosurg 2014;82:1359-68.

57. Manchikanti L, Bakhit CE. Percutaneous lysis of epidural adhesions. Pain Physician 2000;3:46-64.

58. Manchikanti L, Singh V, Cash KA, Pampati V. Assessment of effectiveness of percutaneous adhesiolysis and caudal epidural injections in managing post lumbar surgery syndrome: 2-year follow-up of a randomized, controlled trial. J Pain Res 2012;5:597-608.

59. Avellanal M, Diaz-Reganon G. Interlaminar approach for epiduroscopy in patients with failed back surgery syndrome. Br J Anaesth 2008;101:244-9.

60. Takeshima N, Miyakawa H, Okuda K, et al. Evaluation of the therapeutic results of epiduroscopic adhesiolysis for failed back surgery syndrome. Br J Anaesth 2009;102:400-7.

61. Lee JH, Lee SH. Clinical effectiveness of percutaneous adhesiolysis versus transforaminal epidural steroid injection in patients with postlumbar surgery syndrome. Reg Anesth Pain Med 2013;38:E251.

62. Gruyters I, De Vooght P, Puylaert M, Mestrum R, Van Zundert J, Vanelderen P. Outcome and extent of epidural adhesiolysis attainable with epiduroscopy in failed back surgery syndrome relates to the type of previous lumbar surgery. Eur J Anaesthsiol 2013; 30:207-8.

63. Geypen E, Vanelderen P, Van Zundert J, De Vooght P, Heylen R, Nguyen K. Retrospective analysis of long-term results after spinal endoscopic adhesiolysis for the treatment of failed BSS. Eur J Anaesthesiol 2014;31:218. 
64. Epter RS, Helm S 2nd, Hayek SM, Benyamin RM, Smith HS, Abdi S. Systematic review of percutaneous adhesiolysis and management of chronic low back pain in post lumbar surgery syndrome. Pain Physician 2009;12:361-78.

65. Helm Ii S, Benyamin RM, Chopra P, Deer TR, Justiz R. Percutaneous adhesiolysis in the management of chronic low back pain in post lumbar surgery syndrome and spinal stenosis: a systematic review. Pain Physician 2012;15:E435-62.

66. Manchikanti L, Manchikanti KN, Gharibo CG, Kaye AD. Efficacy of percutaneous adhesiolysis in the treatment of lumbar post surgery syndrome. Anesth Pain Med 2016;6:e26172.

67. Jamison DE, Hsu E, Cohen SP. Epidural adhesiolysis: an evidence-based review. J Neurosurg Sci 2014;58: 65-76.

68. Devulder J, Deene P, De Laat M, Van Bastelaere M, Brusselmans G, Rolly G. Nerve root sleeve injections in patients with failed back surgery syndrome: a comparison of three solutions. Clin J Pain 1999;15:132-5.

69. Fredman B, Zohar E, Ben Nun M, Iraqi R, Jedeikin $\mathrm{R}$, Gepstein R. The effect of repeated epidural sympathetic nerve block on "failed back surgery syndrome" associated chronic low back pain. J Clin Anesth 1999; 11:46-51.

70. Manchikanti L, Singh V, Cash KA, Pampati V, Datta $S$. Preliminary results of a randomized, equivalence trial of fluoroscopic caudal epidural injections in managing chronic low back pain: Part 3: post surgery syndrome. Pain Physician 2008;11:817-31.

71. Hussain AM, Afshan G. Use of pulsed radiofrequency in failed back surgery syndrome. J Coll Physicians Surg Pak 2007;17:353-5.

72. Klessinger S. Zygapophysial joint pain in post lumbar surgery syndrome: the efficacy of medial branch blocks and radiofrequency neurotomy. Pain Med 2013;14:374-7.

73. Arts MP, Kols NI, Onderwater SM, Peul WC. Clinical outcome of instrumented fusion for the treatment of failed back surgery syndrome: a case series of 100 patients. Acta Neurochir (Wien) 2012;154:1213-7.

74. Biondi J, Greenberg BJ. Redecompression and fusion in failed back syndrome patients. J Spinal Disord 1990;3:362-9.

75. Duggal N, Mendiondo I, Pares HR, et al. Anterior lumbar interbody fusion for treatment of failed back surgery syndrome: an outcome analysis. Neurosurgery 2004;54:636-43.

76. Fritsch EW, Heisel J, Rupp S. The failed back surgery syndrome: reasons, intraoperative findings, and longterm results: a report of 182 operative treatments. Spine (Phila Pa 1976) 1996;21:626-33.

77. Markwalder TM, Battaglia M. Failed back surgery syndrome. Part II: Surgical techniques, implant choice, and operative results in 171 patients with instability of the lumbar spine. Acta Neurochir (Wien) 1993;123:129-34.

78. North RB, Campbell JN, James CS, et al. Failed back surgery syndrome: 5-year follow-up in 102 patients undergoing repeated operation. Neurosurgery 1991; 28:685-90.

79. Skaf G, Bouclaous C, Alaraj A, Chamoun R. Clinical outcome of surgical treatment of failed back surgery syndrome. Surg Neurol 2005;64:483-8.

80. Delamarter R, Zigler J, Janssen M. Total disc replacement in the failed back surgery patient: analysis of prospective, randomized and continued access cohorts. Spine J 2011;11(Supple):S151.

81. Taylor RS, Taylor RJ. The economic impact of failed back surgery syndrome. Br J Pain 2012;6:174-81.

82. Bala MM, Riemsma RP, Nixon J, Kleijnen J. Systematic review of the (cost-)effectiveness of spinal cord stimulation for people with failed back surgery syndrome. Clin J Pain 2008;24:741-56.

83. Taylor RS, Ryan J, O’Donnell R, Eldabe S, Kumar K, North RB. The cost-effectiveness of spinal cord stimulation in the treatment of failed back surgery syndrome. Clin J Pain 2010;26:463-9.

84. North RB, Kidd D, Shipley J, Taylor RS. Spinal cord stimulation versus reoperation for failed back surgery syndrome: a cost effectiveness and cost utility analysis based on a randomized, controlled trial. Neurosurgery 2007;61:361-8.

85. Zucco F, Ciampichini R, Lavano A, et al. Cost-effectiveness and cost-utility analysis of spinal cord stimulation in patients with failed back surgery syndrome: results from the PRECISE study. Neuromodulation 2015;18:266-76.

86. Hollingworth W, Turner JA, Welton NJ, Comstock BA, Deyo RA. Costs and cost-effectiveness of spinal cord stimulation (SCS) for failed back surgery syndrome: an observational study in a workers' compensation population. Spine (Phila Pa 1976) 2011;36: 
2076-83.

87. Taylor RJ, Taylor RS. Spinal cord stimulation for failed back surgery syndrome: a decision-analytic model and cost-effectiveness analysis. Int J Technol Assess Health Care 2005;21:351-8.

88. Manca A, Kumar K, Taylor RS, et al. Quality of life, resource consumption and costs of spinal cord stimulation versus conventional medical management in neuropathic pain patients with failed back surgery syndrome (PROCESS trial). Eur J Pain 2008;12:104758.

89. de Lissovoy G, Brown RE, Halpern M, Hassenbusch SJ, Ross E. Cost-effectiveness of long-term intrathecal morphine therapy for pain associated with failed back surgery syndrome. Clin Ther 1997;19:96-112.

90. Melzack R, Wall PD. Pain mechanisms: a new theory. Science 1965;150:971-9.

91. Kleiber JC, Marlier B, Bannwarth M, Theret E, Peruzzi P, Litre F. Is spinal cord stimulation safe? A review of 13 years of implantations and complications. Rev Neurol (Paris) 2016;172:689-95.

92. Avellanal M, Diaz-Reganon G, Orts A, Soto S. Oneyear results of an algorithmic approach to managing failed back surgery syndrome. Pain Res Manag 2014; 19:313-6.

93. Ganty P, Sharma M. Failed back surgery syndrome: a suggested algorithm of care. Br J Pain 2012;6:153-61.

94. Monlezun O, Voirin J, Roulaud M, et al. "MAST" prospective study: value of minimal access spine technologies technique for multicolumn spinal cord stimulation surgical lead implantation in the context of a French multicentre randomized controlled trial (ESTIMET study). Neurochirurgie 2015;61 Suppl 1:S125-30.
95. Roulaud M, Durand-Zaleski I, Ingrand P, et al. Multicolumn spinal cord stimulation for significant low back pain in failed back surgery syndrome: design of a national, multicentre, randomized, controlled health economics trial (ESTIMET Study). Neurochirurgie 2015;61 Suppl 1:S109-16.

96. Racz GB, Heavner JE, Trescot A. Percutaneous lysis of epidural adhesions--evidence for safety and efficacy. Pain Pract 2008;8:277-86.

97. Manchikanti L, Singh V, Cash KA, Pampati V, Datta $S$. Management of pain of post lumbar surgery syndrome: one-year results of a randomized, doubleblind, active controlled trial of fluoroscopic caudal epidural injections. Pain Physician 2010;13:509-21.

98. Deer TR, Caraway DL, Kim CK, Dempsey CD, Stewart CD, McNeil KF. Clinical experience with intrathecal bupivacaine in combination with opioid for the treatment of chronic pain related to failed back surgery syndrome and metastatic cancer pain of the spine. Spine J 2002;2:274-8.

99. Wilkinson HA. Injection therapy for enthesopathies causing axial spine pain and the "failed back syndrome": a single blinded, randomized and crossover study. Pain Physician 2005;8:167-73.

100. Shamji MF, Rodriguez J, Shcharinsky A, Paul D. High rates of undiagnosed psychological distress exist in a referral population for spinal cord stimulation in the management of chronic pain. Neuromodulation 2016;19:414-21.

101. Anderson JT, Haas AR, Percy R, Woods ST, Ahn UM, Ahn NU. Clinical depression is a strong predictor of poor lumbar fusion outcomes among workers' compensation subjects. Spine (Phila $\mathrm{Pa}$ 1976) $2015 ; 40: 748-56$. 